\title{
Padre Montoya e as estratégias de conquista espiritual nas missões do Guairá
}

Father Montoya and the spiritual conquest strategies in Guairá Missions

El Padre Montoya y las estrategias de conquista espiritual en las misiones de Guairá

\author{
Natália Cristina de Oliveira \\ Universidade Federal do Mato Grosso do Sul (Brasil) \\ http://lattes.cnpq.br/4887196652283041 \\ https://orcid.org/0000-0003-4150-278X \\ natdeoliveir@gmail.com \\ Névio de Campos \\ Universidade Estadual de Ponta Grossa (Brasil) \\ http://lattes.cnpq.br/1413368977042742 \\ https://orcid.org/0000-0003-1850-316X \\ ndoutorado@yahoo.com.br \\ Oriomar Skalinski Junior \\ Universidade Estadual de Ponta Grossa (Brasil) \\ http://lattes.cnpq.br/9877722344756463 \\ https://orcid.org/0000-0003-2660-6839 \\ jrskalinski@yahoo.com.br
}

\section{Resumo}

Este artigo tem como objetivo discutir as estratégias de Padre Montoya no processo de conquista espiritual entre os gentios das missões do Guairá, no contexto do século XVII. Apoia-se na obra intitulada Conquista Espiritual feita pelos religiosos da Companhia de Jesus nas Províncias do Paraguai, Paraná, Uruguai e Tape - Reduções Guaraníticas, escrita por esse padre jesuíta e nos conceitos de estratégia e habitus de Pierre Bourdieu, na tentativa de explicitar que a presença dos jesuítas foi demarcada pela denúncia de abusos contra os gentios praticados pelos colonos espanhóis e bandeirantes paulistas, pela descrição elogiosa dos gentios convertidos e pelo combate contra gentios não convertidos, em especial contra caciques e pajés que eram representados como a encarnação do demônio nas terras das Américas.

Palavras-chave: Companhia de Jesus. Missões do Guiará. Antonio Ruiz de Montoya. Conquista espiritual. 


\begin{abstract}
This article aims to discuss Father Montoya's strategies in the spiritual conquest process among the heathens in Guairá missions, in the context of the 17th century. Based on the opus named Conquista Espiritual feita pelos religiosos da Companhia de Jesus nas Províncias do Paraguai, Paraná, Uruguai e Tape - Reduções Guaraníticas, written by this Jesuit Father, also on Pierre Bourdieu's strategy and habitus concepts, this article also attempts to make explicit that the Jesuits' presence was marked out not only by denouncements of abuse committed by the Spanish settlers and the trailblazers from São Paulo against the heathens, but also by the converted heathens' flattering description and by the struggle against the non-converted ones, in particular against chieftains and shamans who were represented as the Devil's incarnation in the American lands.
\end{abstract}

Keywords: Society of Jesus. Guairá Missions. Antonio Ruiz de Montoya. Spiritual conquest.

\title{
Resumen
}

Este artículo pretende discutir las estrategias del Padre Montoya en el proceso de conquista espiritual entre los gentiles de las misiones de Guairá en el contexto del siglo XVII. Se basa en el trabajo titulado Conquista espiritual, escrito por el sacerdote jesuita y en los conceptos de estrategia y hábito de Pierre Bourdieu, por los religiosos de la Compañía de Jesús en las provincias de Paraguay, Paraná, Uruguay y Tape - Reduciones Guaraníticas, en un intento de hacer explícito que La presencia de los jesuitas fue demarcada por la denuncia de abusos contra los gentiles practicados por los colonos españoles y los bandeirantes paulistas, por la digna descripción de los gentiles conversos y por el combate contra los gentiles no convertidos, especialmente contra los caciques y pajés que fueron representados como la encarnación del diablo en la tierras de las américas.

Palabras clave: Compañía de Jesús. Las Misiones de la Guía. Antonio Ruiz de Montoya. Conquista espiritual. 


\section{Introdução}

Este artigo tem como objetivo discutir as estratégias de Padre Montoya (1582-1652) para a efetivação da conquista espiritual entre os gentios das missões do Guairá, no contexto do século XVII. Nossa fonte é a obra intitulada Conquista Espiritual feita pelos religiosos da Companhia de Jesus nas Províncias do Paraguai, Paraná, Uruguai e Tape - Reduções Guaraníticas, escrita por esse padre jesuíta, publicada em 1639, em Madri. A versão portuguesa que utilizamos é oriunda da edição de 1892 que, por sua vez, foi reeditada em 1992. Esse escrito passou por uma reelaboração para ser publicado, pois foi utilizado como documento no processo movido contra os bandeirantes na Corte espanhola. Em razão das minúcias de sua descrição, essa fonte é considerada, no âmbito da história e historiografia, como uma das mais completas e complexas a respeito das missões jesuíticas (PARELLADA, 2013; REBES, 2001).

É possível observar as particularidades da atuação da Companhia de Jesus, em específico, a forma como Montoya construiu a representação da vida dos indígenas e da atuação dos padres no empreendimento das missões. Vale ressaltar que - por meio de leituras - se pode encontrar disparidade entre as datas fixadas na reorganização dos escritos, realizada pelos próprios jesuítas, para publicação. Essa questão pode ser compreendida em razão da distância espacial, entre os escritores e os destinatários das cartas, enviadas aos seus superiores (REBES, 2001). Além disso, é importante dizer que a Companhia de Jesus investe de modo cuidadoso nos "[...] monumentos escritos do seu passado missionário e institucional. A produção de documentos da instituição é monumental, tanto no aspecto da colossal emissão de papeis escritos, quanto na intencionalidade do que foi produzido" (OLIVEIRA, 2015, p. 79) ${ }^{1}$.

Como bem identifica Paulo Rogério Melo de Oliveira (2015), desde a criação da Província Jesuítica do Paraguai, havia interesse em escrever a própria história das missões. Nesse sentido, as cartas e os registros dos padres que estavam em missão constituíram os materiais que documentam a atuação da Companhia de Jesus. As descrições de Montoya estão entre os documentos utilizados pelos historiadores da Ordem, corroborando para a construção de um passado "[...] grande e glorioso, e os feitos edificantes dos grandes homens assumem proporções épicas. Nesta visão monumental destaca-se a chegada heroica dos jesuítas na região e a providencial obra civilizadora junto às populações nativas" (OLIVEIRA, 2015, p. 86).

Nas descrições iniciais do livro, Padre Montoya afirma que a tarefa dos padres da Companhia seria "[...] a de conseguir a paz entre espanhóis e índios: uma coisa tão difícil que, em mais de cem anos desde que se descobriram as índias Ocidentais até o dia atual, ainda não se tornou possível alcançar" (MONTOYA, 1997, p. 18). Essa tarefa hercúlea não poderia ser levada adiante sem estratégias. Desse modo, o conceito de estratégia, apresenta-se "[...] produto do senso prático como sentido de jogo, de um jogo social particular, historicamente definido" e (BOURDIEU, 2004, p. 81) mostra-se útil, pois permite observar como os jesuítas por meio do habitus, sistemas de disposições duráveis, promoveram suas intervenções nas terras missioneiras. Então, compreender as noções de habitus e estratégia é fundamental para analisar a dinâmica dos religiosos no campo em questão, pois,

a existência de um campo especializado e relativamente autônomo é correlativa à existência de alvos que estão em jogo e de interesses específicos: através dos investimentos indissoluvelmente econômicos e psicológicos que eles suscitam entre os agentes dotados de um determinado habitus, o campo e aquilo que está em jogo nele produzem investimentos de tempo, de dinheiro, de trabalho etc. [...] Todo campo,

\footnotetext{
${ }^{1} \mathrm{O}$ artigo Clio na Companhia de Jesus: notas sobre a historiografia jesuítica das reduções do Paraguai, escrito por Paulo Rogério Melo de Oliveira (2015), faz uma importante síntese da historiografia dessa Ordem, conforme produzida pelos padres.
} 
enquanto produto histórico, gera o interesse, que é condição de seu funcionamento (BOURDIEU, 2004, p. 126-128).

As ações práticas de um mesmo agente são objetivamente harmonizadas entre si sem que isto represente uma busca intencional por coerência, e são similares às práticas de outros agentes da mesma classe. Os escritos desse padre são interpretados como expressão do movimento que buscava as conquistas espiritual e territorial, sem deixar de considerar que tal documento é um monumento (LE GOFF, 1994) da Companhia de Jesus. Logo na apresentação da obra, Montoya (1997, p. 18) explicita que sua principal ocupação teria "[...] sido [o] ensino catequético e sua [dos gentios] conversão à nossa santa fé". Na sequência registra que viveu "[...] o tempo todo em busca de feras, de índios bárbaros, atravessando campos e transpondo selvas e montes em sua busca para agregá-los ao aprisco da Santa Igreja e ao serviço de Sua Majestade" (MONTOYA, 1997, p. 18). Mais à frente, ele anota que o empreendimento dos religiosos, no Guairá, resultou no surgimento de 13 reduções ou povoações, cujo efeito foi a transformação de "[...] índios que viviam de acordo com os seus costumes antigos em serras, campos, selva e povoados [...] a povoações grandes e transformados de gente rústica em cristãos civilizados com a contínua pregação do Evangelho" (MONTOYA, 1997, p. 18-19).

Assim sendo, a pretensão é trazer elementos para compreender as formas de relação estabelecidas entre os jesuítas e os gentios que viviam nas missões do Guairá e como esses padres organizaram suas estratégias e ações na tentativa de conformar um novo modo de vida condizente com o cristianismo; e, principalmente, com os princípios católicos.

\section{As missões do Guairá (1610-1631) na Província Jesuítica do Paraguai}

O nome do Padre Antonio Ruiz de Montoya está intrínseco à história das reduções da Companhia de Jesus na Província Jesuítica do Paraguai, especificamente nas missões do Guairá $^{2}$, onde se tornou um dos principais responsáveis pela organização e execução do projeto missionário empreendido no processo colonial. Como destacado por Futata e Toledo (2017), essas missões localizavam-se em parte nos territórios do Paraguai, Argentina, Chile e em regiões brasileiras que abrangiam do Rio Grande do Sul ao Paraná.

O Padre Montoya não se dedicou apenas a falar a língua dos Guaranis, mas também a auxiliar os gentios nas lutas pelos seus direitos, na condição de súditos da Coroa espanhola (MOURA, 2013). De um lado, se a condição dos gentios era de pertencimento à Espanha, caberia aos jesuítas construírem estratégias para efetivação dos direitos, entre eles, o impedimento de serem transformados em escravos pelas frentes das forças dos bandeirantes. De outro, esse relativo protecionismo que se dava nas reduções jesuíticas implicava na contínua circulação do ideário religioso católico e do próprio ethos da cultura europeia e católica.

Padre Montoya, grande articulador dessas atividades das missões, teve uma infância órfã e uma adolescência turbulenta. Ele pediu autorização no Vice-Reino do Peru ${ }^{3}$ para seguir ao Chile num plano de lutar contra os araucanos - assim denominados pelos espanhóis por serem um povo do vale de Arauco, no Chile. Após um sonho misterioso resolve seguir ao Panamá. Antes de partir desejou se confessar, realizou o ato católico com o Padre Juan Domínguez. Na mesma ocasião conheceu o Padre Gonzalo Suárez, de quem se tornou amigo; e, em 1605, Antonio Ruiz de Montoya muda seus rumos, pois ao seguir o conselho de Suárez, decidiu ingressar na Ordem jesuíta. Após

\footnotetext{
2 "Pelo Tratado de Tordesilhas (1494), a Província Guairá era cortada pela linha divisória a leste da sua região. Sendo que este tratado dividia o mundo por uma linha imaginária que corria a 370 léguas do Cabo Verde, com as terras do ocidente pertencentes à Coroa de Castela e as do oriente ao Reino de Portugal [...]" (AGUILAR, 2002, p. 11).

${ }^{3}$ O governo monárquico do Vice-Reino do Peru (1542-1824), instituído pela Coroa espanhola, consistia na divisão da organização administrativa da Espanha na América do Sul. O território era abrangido por parte da América do Sul e América Central.
} 
sete meses no seminário, Padre Diogo de Torres levou Montoya, juntamente com outros noviços, a Córdoba de Tucumã. Ali terminou seu percurso de seminarista, pois, assim como Padre Anchieta, Montoya teve avanço na formação em filosofia e em teologia, o que fez com que se tornasse clérigo mais rapidamente e se envolvesse nas conquistas missioneiras.

Em Córdoba de Tucumán, Montoya recebeu prosseguimento aos seus estudos em letras clássicas e humanidades. No entanto, ele apenas recebeu um curso de teologia moral antes de sua ordenação. Isso leva a crer que exemplos serviram de inspiração para a sua vida religiosa, como a "[...] sabedoria de Inácio, a inspiração de Javier, a amabilidade de Pedro Fabro, a ciência de Lainez, a vida interior de Nadal, bem como as experiências de defesa dos indígenas feitas por José de Acosta e a do dominicano Bartolomé de Las Casas" (MOURA, 2013, p. 68).

A ordenação de Montoya o direcionou e o envolveu de forma efetiva no trabalho das Missões, primeiramente em Guairá. Em 1612, Montoya foi enviado à Província do Guairá para encontrar os padres José Cataldino e Masseta. De acordo com seu relato "[...] haviam passado perto de seis meses, desde que os padres se encontravam no Pirapó, e ano e meio desde sua saída de Assunção, quando o Pe. Diogo de Torres me enviou àquela Província” (MONTOYA, 1997, p. 41).

Há um destaque considerável, a ser feito, entre a sua formação, bem como o seu perfil, se comparado aos de outros missionários religiosos em formação no território nacional; principalmente aqueles que já estavam à frente do catolicismo no Brasil há tempos. A partir de Bourdieu (2004, p. 122, grifos do autor) é possível levantar algumas questões e possibilidades destes padres intelectuais terem se reinventado e possuírem novas definições ao longo dos tempos, considerando que:

onde se tinha um campo religioso distinto tem-se a partir de então um campo religioso de onde se sai sem saber, ainda que apenas biograficamente, já que muitos clérigos se tornaram psicanalistas, psicólogos, assistentes sociais, etc., e exercem novas formas de cura das almas com um estatuto de leigos e sob uma forma laicizada assiste-se então a uma redefinição dos limites do campo religioso, à dissolução do religioso em um campo mais amplo, que se acompanha de uma perda do monopólio da cura das almas no sentido antigo, pelo menos ao nível da clientela burguesa.

Levando em conta a incorporação do habitus religioso e a forma como transitou nos campos de atuação, Padre Montoya foi um clérigo ativo e defensor da Igreja Católica em relação ao Estado e à sociedade. $\mathrm{O}$ inaciano, na concepção bourdieusiana, preservou as tradições religiosas consolidadas e impulsionou, ainda mais, a atuação da Igreja Católica nas conquistas territoriais. $\mathrm{O}$ percurso entre a partida e a chegada foi marcado por um longo período e intensas dificuldades, como descrito abaixo:

Partimos juntos o Pe. Antônio de Moranta e eu. Pela metade do caminho de quarenta dias, em região despovoada, vieram a faltar-nos os tassallhos ou grandes pedaços de charque e a farinha de pau: o que era nossa provisão. Ficou-nos um pouco de milho, do qual tomamos cada um certo punhado ao meio-dia e outro tanto à noite. Tal aperto causou ao padre uma enfermidade muito penosa e, como tivéssemos notícia de que outras dificuldades nos esperassem mais adiante, a necessidade forçou-o a voltar para trás desde o porto de Maracaju (MONTOYA, 1997, p. 41).

Ao verificar a cordialidade com que foi recebido, o Padre Montoya sente-se curioso ao perceber a hospitalidade dos gentios e assim inicia sua missão. 
Durante vários anos sua ação evangelizadora se desenvolveu como missionário itinerante, ao estilo dos primeiros padres na área; administrando batizados e celebrando missas chegou ao lugar que chamavam de Nossa Senhora de Copacabana, em memória do já então bem conhecido Santuário do Alto Peru [...] Neste recorrido visitou aos índios 'Cabelludos' ou 'Coronados', na região do Campo, continuando, depois, em Inheay seu trabalho fomo-nos com pressa três padres rumo a seus ranchos e alojamentos (REBES, 2001, p. 28, grifos do autor).

Padre Montoya não travou apenas conquistas espirituais, mas com apoio da Corte espanhola lutou, ainda, contra bandeirantes de São Paulo de Piratininga e outros que dali se aproximavam com fins à captura dos gentios. O jesuíta transitou por todas as reduções que lhe eram indicadas, principalmente no sul do Brasil, e seu contato se deu, de forma mais detida às tribos Guarani e Jế.

A região, definida por Guairá, localizada ao Sul do Brasil, foi povoada, principalmente, por povos Guarani e Jê. Parellada (2013) ressalta que o Guairá tinha como limites ao norte o rio Paranapanema, ao sul o rio Iguaçu, a oeste o Paraná e a leste as serras de Guarayrú; essas regiões eram banhadas por água doce e propícias para a vivência permanente das tribos. Essa região, integrante da Província Jesuítica do Paraguai, “[...] tinha sua sede 'provincial' em Córdoba da Argentina e, por alguns tempos, até abrangia o Chile" (MONTOYA, 1997, p. 20).

Os jesuítas chegaram ao Guairá no ano de 1610. Ele descreve que Padre Diogo de Torres enviou à Guairá os italianos Padre José Cataldino e Padre Simão Masseta. A presença desses padres inscrevia-se no contexto de "[...] uma nova frente expansionista no interior da província em sequência a expansão promovida por Domingo Martinez Irala, em 1557, com a fundação da Ciudad Real" (SILVA, 2011, p. 97). A presença espanhola se deu, também, por meio da criação de reduções. Por vezes, se dava sob a administração de um colono espanhol indicado pela Coroa. Ocorriam muitos conflitos, razão pela qual foi outorgada aos jesuítas a tarefa de cristianizar os gentios. As ações dos jesuítas tiveram início com duas unidades e estenderam-se a 13 missões, conformando as "[...] Reduções Guaranis do Paraguai de antanho e assim hoje, não em último lugar, sobre os atuais Estados Brasileiros do Paraná e do Rio Grande do Sul, devido ao Guaíra e ao Tape" (BRUXEL; RABUSKE, 1983, p. 9-10).

Segundo André Luís Freitas da Silva (2011, p. 68), o interesse missionário “[...] dos jesuítas pelos nativos que habitavam a região da governação do Paraguai começou a se cristalizar logo após os primeiros passos da Companhia de Jesus na América". Esse autor referese ao momento em que chegaram os jesuítas portugueses, ano de 1549. No entanto, segundo Silva (2011, p. 70), “[...] somente em 1567 chegaram os primeiros jesuítas ao Vice-Reino do Peru. Um ano após a chegada desses religiosos foi criada a Província Jesuítica do Peru". Em decorrência disso, "[...] o território paraguaio que antes pertencia à esfera religiosa dos jesuítas do Brasil, passou a pertencer à nova província" (SILVA, 2011, p. 70).

Freitas da Silva (2011, p. 71) assegura que a "[...] Companhia de Jesus atuava nas terras portuguesas desde 1549 e nas terras altas do Peru desde 1568. Somente em 1586 recebeu autorização para evangelizar no Paraguai”. Em 1606, foi autorizada a criação da Província Jesuítica do Paraguai, embora ela "[...] somente se concretizou em 1607 com a chegada do primeiro provincial Diego de Torres Bollo" (SILVA, 2011, p. 72). Padre Montoya (1997, p. 34) assim descreve a fundação dessa Província: "[...] Pe. Diogo de Torres, tendo sido nomeado primeiro Provincial da Província do Paraguai, deu começo feliz à sua Província". Essa repartição missionária passou a ser responsável pela administração religiosa dos governos civis

\footnotetext{
4 “[...] por mais que a população Guarani tenha sido superior em número a outras populações indígenas reduzidas e terem exercido uma influência política, sociocultural e econômica maior que outros grupos, aqui queremos enfatizar a participação das outras populações índias no âmbito das reduções organizadas nas regiões do Guairá, Tape, Uruguai, Itatim e Paraná” (SILVA, 2011, p. 87).
} 
do Chile, Tucumã, Paraguai e Buenos Aires. Porém, em 1626, o Chile passou a ser de responsabilidade da Província Jesuítica do Peru. Depois disso, "[...] o território da Província Jesuítica do Paraguai estava formado pelas terras das governações civis de Tucumã, Paraguai, Buenos Aires e parte da governação civil de Santa Cruz da Serra" (MONTOYA, 1997, p. 34). ${ }^{5}$

Durante o século XVI, essas reduções tomavam os moldes das cidades espanholas, seguindo a estrutura codificada em 1573 pela lei urbanística de Felipe II. O formato seria:

um 'enxadrezado de ruas retilíneas', que definiam uma série de quadras iguais, quase sempre quadradas, sendo que no centro da cidade ficava a praça. Ainda esta lei ressaltava que os terrenos ao redor da praça não deveriam ser concedidos a particulares, mas sim reservados à Igreja (PARELLADA, 2013, p. 252, grifos do autor).

Já em 1503, como indica Silva (2011, p. 75, grifos do autor), “[...] o governador de La Española Frei Nicolas de Ovando (1502-1509), recebeu instruções no sentido de agrupar os índios em pueblos, onde os indígenas deveriam ter 'terras para cultivo e cria de animais', além de "igreja, capelão e alguém para exercer justiça e governo". Entretanto, como bem registrou Padre Montoya (1997, p. 54), viviam “[...] os gentios em povoações muito pequenas, mas não sem governo. Tinham eles os seus caciques, em quem todos reconhecem nobreza herdada de seus maiores, com o fundamento de que haviam tido vassalos e governado povo". Muito embora essa descrição do jesuíta, o modelo prescrito pelos europeus "[...] estava acompanhado de novos mecanismos de controle e administração social, que eram estranhos ao cotidiano nativo, tais como: as práticas econômicas, sociais, políticas e religiosas importadas do velho continente" (SILVA, 2011, p. 75). Estava em curso a circulação de um modelo ideal de organização que carregava concepções diversas das vividas pelos gentios, aspectos que ao serem engendrados, “[...] alteravam profundamente o modo de ser e de viver das populações que aceitaram a nova condição de vida" (SILVA, 2011, p. 75). De outro lado, esse modelo ideal perpassava pelo complexo processo de apropriação, aspecto demarcado pelas estratégias de ação missioneiras dos jesuítas.

No século XVII, a Coroa espanhola investiu de modo contínuo na organização colonial, associando essa tarefa ao trabalho das reduções. Conforme Sergio Luis Alberto Páez (2013, p. 167), naquele contexto "[...] la Corona Española decidió subvencionar a los misioneros con el propósito de explorar y terminar de definir la territorialidad que le daban los tratados con Portugal". Essa condição implicou o estabelecimento de alguns direitos aos índios, entre eles a proibição de serem transformados em escravos. De acordo com Páez (2013, p. 167) “[...] ante estas medidas de la Corona, los comerciantes españoles reaccionaron aliándose con los portugueses. Esto generó la formación de ejércitos de cazadores de esclavos, tentados por la concentración de indios en las misiones".

Conforme explicita Silva (2011, p. 78), “[...] a organização das reduções era orientada pelo traçado urbano 'al modo de los del Perú' ou da maneira que os índios melhor se adaptassem". Mais tarde, passaram a ter outro modelo, em particular quando em meados do século XVIII,

o jesuíta José Cardiel, citado por Guillermo Furlong, observou que as reduções de Guarani possuíam um mesmo traçado urbano, com 'plaza muy capaz de 160 varas en cuadro, las calles todas en cordel de 16 ó 15 varas en ancho; las casas son en algunos pueblos de piedra e otros de piedra solo cimentos' (SILVA, 2011, p. 78).

\footnotetext{
${ }^{5}$ De acordo com Silva (2011, p. 72), Moacir Flores esclarece que "o território da Província Jesuítica do Paraguai abrangeria as repúblicas da Argentina, Uruguai, Paraguai, sul da Bolívia, partes do sul e centro-oeste do Brasil”.
} 
A exposição até aqui reitera que a "[...] expansão ocidental caracterizou-se pela bifrontalidade: por um lado, incorporavam-se novas terras, sujeitando-as ao poder temporal dos monarcas europeus; por outro, ganhavam-se novas ovelhas para a religião e para o papa" (SOUZA, 1986, p. 32). É importante ressaltar que os recursos minerais, como os contidos no Tambo das minas de ferro, do Guairá atraiam a atenção dos governantes no que tange à capitalização financeira. Na segunda metade do século XVI, o sistema de rendas apresentavase comprometido pela resistência indígena. Diante disso, os padres da Companhia de Jesus foram convidados pelo governador de Assunção, Hernadárias de Saavedra, para se aproximarem e dominarem o território. O objetivo seria que os jesuítas, já conhecidos pelo poder de domínio dos gentios, fundassem as reduções, pois conforme atesta André Luís Freitas da Silva (2011, p. 67), eles "[...] se deslocaram ao novo mundo para civilizar e propagar a fé católica. Agindo dessa maneira eles acreditavam estar salvando a alma das populações nativas que viviam numa espécie de infidelidad diante de Deus".

Os inacianos eram conhecidos pela destacada resistência e forma de domínio territorial. É importante dizer que:

os padres, além da resistência dos indígenas em aderir ao projeto reducional, tinham que conter os encomenderos das vilas espanholas e os bandeirantes paulistas. Estes vinham retirar os índios já aculturados para trabalhar em suas plantações de trigo em São Paulo (PICANÇO; MESQUITA, 2010, p. 68).

A encomienda consistia no direito dado ao colono em explorar o trabalho indígena. Nas encomiendas espanholas, um grupo de gentios era confiado pelo rei a um colono e a seus descendentes, pelo prazo de duas ou três gerações, para que os protegessem e os instruíssem na fé católica. Como recompensa pelo trabalho, aquele encomendeiro recebia em bens ou dias de trabalho o tributo que os índios vassalos produziam ao rei da Espanha (PARELLADA, 2013). O ingresso dos jesuítas objetivava estabelecer relações de paz entre espanhóis e gentios, utilizando-se da estratégia de cristianização dos povos das reduções. De acordo com Bourdieu (1996, p. 61):

É no horizonte particular dessas relações de força específicas, e de lutas que tem por objetivo conservá-las ou transformá-las, que se engendram as estratégias dos produtores, a forma de arte que defendem, as alianças que estabelecem, as escolas que fundam e isso por meio dos interesses específicos que aí são determinados.

São essas estratégias, no campo de conquista territorial e espiritual, que contribuem para o estabelecimento da Ordem jesuítica nas missões empreendidas. Essas estratégias funcionam como lugares de poder impondo, de forma mais alinhada ao convencimento, regras aos indivíduos em jogo. Nesse sentido, "[...] o projeto missioneiro da Companhia de Jesus surgiu como uma proposta alternativa diante da brutalidade do regime da encomienda e da escravidão gerados nas cidades de Assunção e São Paulo, respectivamente" (SNIHUR, 2007, p. 236 apud SOSTER, 2014, p. 26-27).

Assim, os jesuítas passaram a atuar nas reduções. É interessante anotar a definição registrada por Montoya (1997, p. 35).

Chamamos de "Reduções" aos "povos" ou povoados de índios que, vivendo à sua antiga usança em selvas, serras e vales, junto a arroios escondidos, em três, quatro ou seis casas apenas, separados uns dos outros 
em questão de léguas ${ }^{6}$ duas, três ou mais, "reduziu-se" a diligência dos padres a povoações não pequenas e à vida política (civilizada) e humana, beneficiando algodão com que se vistam, porque em geral viviam na desnudes, nem ainda cobrindo o que a natureza ocultou.

De um lado, conforme os relatos de Padre Montoya, no processo de conversão dos gentios, os jesuítas combatiam o que denominava de abusos de certos ritos dos índios guaranis e pregavam a fé cristã. Ele observa que:

incita-me a procurar esta pacificação a caridade cristã, o desamparo total dos índios. $\mathrm{O}$ fato de estar fazendo quase trinta anos que, sem deixar-me desviar a outro encargo qualquer, minha principal ocupação tenha sido seu ensino catequético e sua conversão à nossa fé (MONTOYA, 1997, p. 18).

De outro, suas descrições evidenciam o estranhamento perante os abusos praticados pelos espanhóis que dirigiam as encomendas e a condenação da contínua presença dos bandeirantes paulistas que sequestravam e transformavam os povos das missões em escravos. Essa situação pode ser percebida em registro de sua chegada a uma redução das missões, quando contabilizou que - naquele local - existiam 170 famílias e mais tarde, ao retornar àquela região, não contavam mais de 50 (MONTOYA, 1997). Nesses termos, nisso, também, estava contida a presença dos padres, pois buscava-se por meio "[...] do trabalho de evangelização da Companhia de Jesus uma abordagem integradora em relação aos povos indígenas, que eram alvo de constantes ataques bandeirantes" (SOSTER, 2014, p. 26).

A primeira missão teve início com Padre Marcial de Lorenzana - fundador da primeira Redução, da Companhia de Jesus, na Província. Para solidificar essa realização, em seguida, Montoya destaca em suas anotações: "[...] envio o Pe. Diogo de Torres à cidade de Guaíra, ao Pe. José Cataldino e ao Pe. Simão Masseta, sendo ambos eles italianos, valorosos missionários e filhos fiéis da Companhia, bem como apóstolos daquele gentilidade" (MONTOYA, 1997, p. 37). Nessa cidade, os padres cumpriram seus ministérios, seguindo, posteriormente, a Vila Rica que ficava a 60 léguas de Guairá, onde "[...] exerceram os seus ministérios sacerdotais, e foi com grandíssimo aproveitamento das almas. Depois de haverem cumprido com a sua missão entre os espanhóis, os padres colocaram a sua mira na conversão dos índios, a quem haviam sido enviados" (MONTOYA, 1997, p. 38-39). Nessa sequência, os padres:

Navegaram por esse rio [Paranapanê] acima dez ou onze dias, estando a suas margens despovoadas de tudo, mas, por fim, deram num "pueblo" situado à beira do mesmo rio, sendo que por um lado o cercava um grande arroio, de nome Pirapó. Nele viviam cerca de 200 índios, que recepcionaram com muito amor os padres. Ali levantaram estes o estandarte da cruz, construíram uma pequena choça para servir de igrejinha e lhe deram por título o de Nossa Senhora de Loreto. (MONTOYA, 1997, p. 39).

De acordo com Padre Montoya (1997, p.39), os padres seguiram em busca de novos povoados, ao longo desse rio, chegando a localizar "[...] 25 pequenas aldeias e outras com número maior de pessoas. Em seus discursos deram os padres aos gentios a razão de sua vinda, que era a de fazê-los filhos de Deus e libertá-los da escravidão do demônio" (MONTOYA, 1997, p. 39). Assim, os padres Masseta e Cataldino fundaram, em 1610, no vale do Paranapanema, a missão de Nossa

\footnotetext{
${ }^{6}$ Uma légua equivalia entre 4 e 6 quilômetros.
} 
Senhora de Loreto, na sequência Santo Inácio Mini ${ }^{7}$. A localização da redução jesuítica de Nossa Senhora do Loreto encontra-se, atualmente, na cidade de Itaguajé no Estado do Paraná. Nas imediações de Vila Rica, Tambo das Minas de Ferro, atualmente Nova Cantu, no Estado do Paraná, ficava Itacuru, Santa Ana, Itupá, Tambo e Cunhanguirá. Os povos distribuíam-se por todo o Guairá, às margens do rio Ivaí. Isso tornavam necessárias longas e desgastantes viagens entre Assunção e o Guairá para que os padres jesuítas pudessem atender todos os povos.

A presença dos padres estava contida na própria organização do projeto colonial, conforme já destacado por Laura Melo e Souza (1986). Entretanto, essa condição não implicava que as missões seriam um processo fácil, pois as relações sociais nesses espaços eram demarcadas por confluências, mas também por conflitos de interesses entre os jesuítas, os colonos espanhóis que dirigiam as reduções, os caciques dos diversos povoados do Guiará, os bandeirantes de São Paulo e os gentios. Desse modo, os missionários estavam envoltos a essas complexas relações para levar em frente sua cruzada pela cristianização na região das missões.

\section{Da complexidade das relações sociais nas terras missioneiras}

Os povos Guarani e Jê tiveram os seus primeiros contatos com viajantes europeus que saiam do litoral atlântico e moviam-se ao Paraguai. Alguns fatos levam a crer que essa convivência com povos europeus era contínua, conforme atestam estudos arqueológicos:

a maioria da cerâmica era confeccionada pelos índios Guarani, apesar de muitos artefatos mostrarem influência europeia como, por exemplo, os motivos florais, as incisões com detalhes barrocos e a associação de vários tipos de decoração, tais como pintura e incisão. As formas e os padrões decorativos diferenciados dos vasilhames cerâmicos dos índios Guarani e dos espanhóis, e até mesmo os hábitos alimentares, também manifestam diferenças étnicas (PARELLADA, 2013, p 253).

Como descrito, a principal atividade econômica dos indígenas - principalmente os Guaranis - que povoavam o Guairá, era a extração e transporte da erva-mate, realizada pelo sistema de encomendas (PARELLADA, 2013). No entanto, a relação entre os espanhóis e os gentios foi conformada por muitos conflitos, como descreve Padre Montoya. Isso parece ser um dos aspectos que constituíram as complexas relações estabelecidas nas terras das missões, pois os jesuítas passaram a ser porta-vozes dos reclamos junto à Coroa espanhola de abusos praticados contra os gentios. Compreendemos que tais ações, bem como tamanha confiabilidade, são possíveis por meio do habitus que consiste em

estruturas estruturadas predispostas a funcionar como estruturas estruturantes, isto é, como princípio gerador e estruturador das práticas e das representações que podem ser objetivamente 'reguladas' e 'regulares' sem ser produto da obediência a regras, objetivamente adaptadas a seu fim sem supor a intenção consciente dos fins e o domínio expresso das operações necessárias para atingi-los e coletivamente orquestradas, sem ser o produto da ação organizadora de um regente (BOURDIEU, 2003, p. 54).

\footnotetext{
${ }^{7}$ O Padre Ruiz de Montoya, em auxílio de outros padres, contribuiu, ainda, com a fundação de reduções, como São Miguel, em 1626 com o Padre Critóbal de Mendoza; Imaculada Conceição, em 1627 com o Padre Francisco Diaz Taño; e, Santo Antônio, em 1627.
} 
Assim, entendemos o habitus enquanto produto das relações sociais estabelecidas, sobretudo, no campo católico, e como mecanismo às estratégias utilizadas para dominação do campo em questão. Essa incorporação auxilia Padre Montoya nos campos de atuação e em sua militância ativa como defensor dos princípios missioneiros católicos e às causas envoltas a estes princípios - bem como a catequização dos povos indígenas.

Sua narrativa, já no início do livro, evidencia o que denomina de abusos praticados pelos espanhóis e das reações dos gentios. No período em que ficou em Maracaju, em razão da enfermidade de Padre Moranta, um dos missioneiros jesuíta e acompanhante de conquistas, além de administrar aos gentios os sacramentos católicos, Padre Montoya (1997, p. 42) relata as condições desses povos que trabalhavam com moagem de erva e destaca: "[...] durante o dia inteiro estes não comem mais do que fungos, frutas ou raízes silvestres, que para sua ventura se lhes oferecem nos matos, estando eles em contínua ação e trabalho". Além disso, observa que havia controles realizados por um capataz: "[...] apenas o pobre índio se assentou um pouco para tomar fôlego, faz-lhe sentir a sua ira, envolta em palavras e, por vezes, em pauladas" (MONTOYA, 1997, p. 42). O padre assevera ainda, acerca daquelas atividades: “[...] o trabalho naquela erva tem consumido a muitos milhares de índios. Sou testemunha ocular quanto à existência naqueles matos de ossários bem grandes de índios" (MONTOYA, 1997, p. 42). Nem comida os gentios tinham, pois ao não encontrarem animais para suprir sua fome, consumiam a própria erva como alimento, "[...] inchando-se-lhes os pés, as pernas e o ventre, mostrando seu rosto apenas ossos, e palidez a figura da morte" (MONTOYA, 1997, p. 42).

O jesuíta destaca que o consumo dessas ervas não era uma prática recorrente entre os gentios denotando que passaram a fazer isso em razão da intensa carga de abuso praticada pelos colonos espanhóis que administravam as colônias. A esse respeito, sustenta Montoya (1997, p. 45): "[...] o que descobri como coisa averiguada é que, nos tempos em que esses velhos [de 80 ou 100 anos] ainda eram moços, não se bebia, nem ainda se conhecia". Além disso, descreve que "[...] os naturais da terra ou os índios tomam-na com moderação uma vez por dia. Os espanhóis encontraram nela remédio contra todos os males. Os efeitos vêm a ser que ela os alenta (estimula) ao trabalho e lhes serve de sustento" (MONTOYA, 1997, p. 45).

Em outra passagem, Montoya (1997, p. 44) anota a existência de outra prática recorrente do que considerava abuso dos espanhóis contra os gentios:

sou testemunha de que na Província de Guaíra o encomendeiro mais justo ou correto se servisse por seis meses de cada ano de todos os índios que tinha por encomenda, sem pagar-lhes coisa nenhuma. E os que eram menos justos detinham-nos de dez a doze meses.

Perante essa situação, o jesuíta indaga (1997, p. 44): “[...] sendo isso assim, como na verdade o é, quanto tempo sobra a este desgraçado, para sustentar a sua mulher e criar a seus filhos?". Essa situação descrita por Montoya resultou, de acordo com Sergio Venturini, em muitas interpelações feitas à Coroa espanhola.

Em mais de uma oportunidade houve discussão entre os jesuítas e as autoridades espanholas em relação ao pagamento dos impostos. O rei determinava um valor de imposto, que correspondia a um peso por ano para cada índio adulto. Os padres afirmavam que era menor o valor a ser pago, e questionavam defendendo a ideia de que o Guarani, enquanto soldado, não deveria pagar impostos e, sim, ser indenizado pelo governo (VENTURINI, 2009, p. 44 apud SOSTER, 2014, p. 27). 
Essa tomada de posição em favor desses povos reaparece quando ele passa a associar as resistências ou até as práticas de atos de violência praticadas pelos gentios contra os espanhóis como "[...] efeitos do descuido em não tratar bem os índios" (MONTOYA, 1997, p. 46). A primeira situação retrata gentios que não aceitam o evangelho. Dessa maneira, destaca: “[...] tem a cidade da Assunção à sua frente, duas nações, sendo uma delas se chama Guaicurus e Guaicurut a outra que não reconheceram o cristianismo". Nesses povoados, conforme Montoya (1997, p. 46):

Não semeiam ou não fazem plantações, mas colhem das roças dos espanhóis, furtando quanto podem. Ordinariamente invadem as estâncias de gado, matam o que querem, roubam ao dono o sebo e a carne, vendendo esta. Com toda a segurança vão à cidade e nela circulam, mas suas terras não a têm os espanhóis que nela entram, porque degolam a um espanhol com a mesma facilidade com que matam uma vaca, e porque tamanha é sua ferocidade, que não consegue corrigi-los o poder dos espanhóis.

Mesmo com essa descrição de um grupo violento, denominado por ele de gente bárbara, de costumes bestiais, não deixava de observar que a conversão ao cristianismo seria a estratégia a manter-se. Em outra situação, registra as reações de gentios já batizados no cristianismo, destaca: "[...] viram-se esses índios tão oprimidos pelo contínuo trabalho [...] que a necessidade os forçou a todos a buscarem desafogo. Rebelaram-se, pois, mataram a um bom número de espanhóis e aos sobreviventes foi preciso deixar a cidade de seus bens" (MONTOYA, 1997, p. 48).

Esses fragmentos indicam como a narrativa de Montoya reafirmava a violência existente nas reduções criadas pela Coroa espanhola. Essas notas são corroboradas pela interpretação de Rebes (2001, p. 18),

uma situação particular, porque sua atividade não se limitou a informar somente seus atos; muitos de seus escritos - como as cartas a outros padres, ao vice-rei, assim como os testemunhos - contém uma importante descrição e análise crítica da situação em que os índios viviam. Em alguns se destaca a situação de injustiça, pelo mal-trato que recebiam os índios, propondo soluções para evitá-las.

Essa posição de Montoya gerou conflitos com os próprios colonos espanhóis, conforme atesta sua descrição de que seus superiores estavam preocupados "[...] com os informes que certos espanhóis da Vila Rica lhes fizeram, no sentido de que andávamos ociosos e não fazíamos outra coisa que deixar passar o tempo, e que por isso convinha tirar-nos dali" (MONTOYA, 1997, p. 67). Não era uma convivência harmoniosa, pois a condição de chefe das missões religiosas do Guairá impunha-lhe a responsabilidade de fazer cumprir o estatuto de cidadania que a Coroa espanhola estabeleceu aos gentios de suas colônias.

Outra frente permanente de atuação dos jesuítas consistia na luta contra os bandeirantes de São Paulo. Esses circulavam pela região em busca de riquezas e de gentios para serem usados como escravos nas terras da colônia portuguesa.

Custando uma quinta parte do preço de um negro importado, o índio cativo se converteu no escravo dos pobres, numa sociedade em que os europeus deixaram de fazer qualquer trabalho manual. Toda tarefa cansativa, fora do eito privilegiado da economia de exportação, que cabia aos negros, recaía sobre o índio (RIBEIRO, 1995, p. 100 apud SOSTER, 2014, p. 29). 
Ao referir-se ao grupo originário de São Paulo, Montoya (1997, p. 141) sustenta: “[...] é seu 'instituto' (norma consagrada!) destruir o gênero humano, matando a seres humanos, se estes, para fugirem da miserável escravidão em que os põem, lhes escapem". Relata também que os bandeirantes passavam anos em busca de gentios. Em certo momento o padre jesuíta (1997, p. 142) descreve: "[...] entrou essa gente em nossas reduções: cativando, matando e despojando altares". Diante disso, informa (1997, p. 142): "[...] fomo-nos com pressa três padres rumo a seus ranchos e alojamentos, onde já retinham muita gente presa. Pedimo-lhes que nos devolvessem os que haviam cativado, pois não eram poucos os que possuíam acorrentados". De outra parte, "[...] como loucos frenéticos gritaram de imediato, dizendo: 'prendam-nos! Prendam-nos, pois são traidores!' Juntamente dispararam alguns arcabuzes, ferindo oito ou dez dos índios que nos acompanhavam. Morreu um deles, ali mesmo" (MONTOYA, 1997, p. 142, grifos do autor).

A ação dos bandeirantes não poupava nem aos gentios, nem aos padres. Nas circunstâncias, o Padre José Dómenech foi aprisionado pelos paulistas. E em voz alta diziam que não eram "[...] sacerdotes, mas demônios, hereges, inimigos de Deus, e que pregávamos mentiras aos índios. Apontou um deles a sua escopeta na direção do meu peito, sendo que eu lhe abri a minha roupa, a fim de que a bala entrasse sem resistência" (MONTOYA, 1997, p. 142). As descrições dão ares de intensa crueldade, destacando que destroçavam gentios a machadadas, entravam nas igrejas onde os índios se refugiavam e os matavam - "como no matadouro se matam vacas" (1997, p. 142), descartavam ou destruíam os objetos sagrados sem nenhum pudor. Ao retornarem a São Paulo, ateavam fogo nas choças, queimando "[...] muitíssima gente com inumanidades de feras" (MONTOYA, 1997, p. 144).

O retorno a São Paulo contava com muitos gentios aprisionados. Os padres seguiam para pedir à justiça paulista que interviesse em defesa dos gentios e em cumprimento da legislação que protegia esses povos. Montoya (1997) descreve que os jesuítas, ao chegarem a São Paulo, pediram por justiça, mas não foram ouvidos. Os relatos das invasões dos paulistas são extensos e intensos, detalhando as práticas cruéis cometidas contra os gentios e a própria destruição das reduções, como a de Vila Rica. As reações consistiam na luta empunhada pelos próprios gentios, as interpelações feitas pelos padres e as fugas antes da chegada dos bandeirantes. Em regra, a interpelação feita aos bandeirantes e à justiça de São Paulo, parece ter pouco efeito, conforme descrição anterior.

Outra medida empreendida pelos jesuítas contra os bandeirantes paulistas foi apelar à própria Coroa. Segundo Silvio Ruiz Paradiso (2012, p. 202) "'[...] Montoya em 1637 (em nome do governador, do Bispo do Paraguai e dos chefes das ordens) apresentou uma reclamação formal a Filipe IV da Espanha, sobre a política portuguesa de envio de expedições às regiões vizinhas, na América espanhola". Além disso, "[...] Montoya também foi o padre jesuíta encarregado de se queixar diretamente ao rei de Portugal, sobre os bandeirantes paulistas que atacavam as missões jesuítas em busca de índios para serem vendidos" (PARADISO, 2012, p. 202). Essa situação parecia ser uma das grandes lutas desses jesuítas, pois "[...] desde o ano de 1628 até os tempos presentes, não cessaram eles de combater a cristãos, de cativá-los e vendê-los" (MONTOYA, 1997, p. 146).

A organização de fuga antes da chegada dos bandeirantes mostrou-se uma possibilidade diante das fracassadas demais medidas. Assim, em 1629, acataram a determinação de Assunção e de Madri e mobilizaram a saída dos índios de Loreto e Santo Inácio. A preparação da fuga é recheada de detalhes, de táticas empregadas frente à falta de proteção alguma por parte das forças espanholas contra as cruzadas dos bandeirantes. Os gentios de Loreto e Santo Inácio estavam entregues as suas próprias ações e táticas. Não deixaram acomodar-se: “[...] fabricaram, em tempo brevíssimo, 700 balsas, sem contar canoas em quantidade, embarcandose nelas mais de 12.000 almas" (MONTOYA, 1997, p. 153).

As lutas dos gentios e dos padres não se davam apenas contra os paulistas, mas também contra os próprios espanhóis que viviam em Guairá; como relata Montoya (1997, p. 153-154): "[...] estavam nos aguardando num espaço estreito e perigoso, próprio do célebre Salto do Paraná, em cuja ribanceira eles haviam levantado uma fortaleza de troncos, visando, impedir-nos a 
passagem e cativar a nossa gente". Os padres interpelaram esses espanhóis para que declinassem dessa ação, resultando em petição bem sucedida após longas negociações. Após esse ponto do rio que se mostrava impossível de navegação, os povos seguiram sua fuga por terra.

Após oito dias de viagem por terra, retornam - novamente - a navegar (MONTOYA, 1997). Essa peregrinação foi longa e de muito sofrimento, sendo que em 1632, refundaram as duas reduções no que hoje é o território da Argentina. A fuga foi descrita em analogia ao êxodo bíblico, tamanha a peripécia desse empreendimento.

Ao sair esse povo israelítico, imitador de Jacó, fugindo de gente bárbara, sentados à margem daquele rio, fazendo terna menção de suas dificuldades, do afã e pobreza em que se viam afugentados de suas próprias terras, por aqueles mesmos que, se fizessem uso de sua razão, deviam ampará-los -, lembravam-se os índios com carinho de suas casas, mas principalmente de Deus, onde fora por eles, durante não poucos anos, adorado e humildemente servido, e hospedado em suas almas no Sacramento vivificante (do Altar) (MONTOYA, 1997, p. 157).

Uma das facetas das missões foi, sem dúvida, denunciar e lutar contra os abusos a que estavam submetidos os gentios, seja pelas forças dos colonos espanhóis ou por bandeirantes de São Paulo. Padre Montoya era o chefe das missões na Província Jesuítica do Paraguai. Além disso, era quem endereçava reclamações às autoridades sobre os abusos praticados pelos bandeirantes.

Paralelamente à descrição dos abusos praticados contra os gentios, os relatos indicam que os primeiros contatos de Padre Montoya com esses povos foram de muita empatia. Ele destaca: "[...] acolheram-me os índios desse povoado com grande amor" (MONTOYA, 1997, p. 41). Trata-se, sem dúvida, de sua chegada a redução já constituída por gentios batizados. Porém, mesmo em reduções que resistiam à cristianização, ele elogiava a solicitação feita pelo poder civil aos jesuítas, reconhecendo que "[...] esforçaram-se os governadores no sentido de que os padres da Companhia domesticassem essa gente bárbara através do Evangelho" (MONTOYA, 1997, p. 47). Muito embora, ele admitisse a dificuldade dessa tarefa e o fracasso de certas missões dos jesuítas, não deixava dúvida em suas descrições da cruzada a que estavam afeitos esses padres. Sobre esse aspecto ele destaca:

desta difícil empresa ficou encarregado o Pe. Pedro Romero. Tentou esse padre, com eles os estratagemas, que seu desejo fervoroso lhe inspirava, para arrancá-los de seus costumes bestiais e implantá-los no Cristianismo. Não o conseguiu em muitos anos, porque eles se burlavam de nossa fé. Confirmavam com isso seus costumes bestiais, e tenazmente estão resolvidos a assim viver até a morte (MONTOYA, 1997, p. 47).

Em outro momento, Padre Montoya não utiliza essa adjetivação negativa para referir-se aos costumes dos guaranis. Sob o título "ritos dos índios guaranis" descreve diversas representações e práticas existentes entre eles.

Conhecemos a alguns caciques, que possuíam até 15, 20 e 30 mulheres. Nunca tiveram ídolos, embora o demônio já lhes estava impondo a ideia de venerarem os ossos de alguns índios, que em vida haviam sido magos famosos. Ao cativo colhido em guerra engordam-no, dando-lhe liberdade quanto a comida e mulheres, que escolhe a seu gosto. Já estando gordo, matam-no com muita 
solenidade. Todos tocam com a mão nesse corpo morto. Pela comarca repartem porções desse corpo (MONTOYA, 1997, p. 56).

São vários os ritos descritos. Não faz um juízo de valor desses diversos rituais. Entretanto, na sequência da organização do diário constam descrições sob o título "nosso modo de tirar tais abusos e de pregar a fé". A primeira nota é que dois padres viviam em cada povoado. Além disso, observa que fundaram ali uma escola para crianças e jovens; e, aos adultos, descreve: "[...] fixou-se o tempo de uma hora pela manhã e de outra à tarde, para que todos viessem à catequese ou doutrina" (MONTOYA, 1997, p. 59). A julgar por esses fragmentos observa-se o investimento na conformação de novas representações e práticas, com atividades destinadas às crianças, aos jovens e adultos, aspecto que evidencia que uma das primeiras tarefas dos jesuítas era o domínio da língua dos gentios.

Futata e Toledo (2017, p. 71) destacam que Padre Montoya “[...] desempenhou um projeto apostólico-político, pois, dedicou sua vida missionária na conversão, civilização e defesa dos indígenas, [...] de modo que, o missionário recebeu o título de apóstolo do Guairá". Nesse mesmo sentido, levamos em consideração a afirmação de Aguilar (2002) em que assevera que Padre Montoya era considerado um apóstolo do Guairá por conseguir contribuir com a expansão das missões, no estabelecimento das reduções, na defesa dos gentios no que diz respeito aos tentados dos inimigos; e, sobretudo, com a cristianização. Atribuímos essa posição em que se encontrava Padre Montoya, principalmente, ao exercício do habitus jesuítico - isso, sem dúvidas, favorecia seu reconhecimento em legitimar e impulsionar as conquistas da Igreja Católica. Esse posicionamento contribui com seus discursos, registros e ações.

O porta-voz autorizado consegue agir com palavras em relação a outros agentes e, por meio de seu trabalho, agir sobre as próprias coisas, na medida em que sua fala concentra o capital simbólico acumulado pelo grupo que lhe conferiu o mandato e do qual ele é, por assim dizer, o procurador (BOURDIEU, 2008, 89).

Ao lado desse processo formativo, a própria forma de viver dos jesuítas constituiu-se em uma estratégia de conformação de novos modos de vida entre os gentios. O jesuíta relata que, embora tratassem nos sermões dominicais, "[...] com toda clareza os mistérios de nossa fé e os preceitos divinos, quanto ao sexto mandamento [castidade] por ora guardamos silêncio em público" (MONTOYA, 1997, p. 59). Aqui parece residir um bom indicativo das diferenças morais pregadas pela doutrina cristã e a experiência dos gentios. Pe. Montoya (1997, p. 59) anota:

procurou o demônio tentar a nossa pureza ou castidade, oferecendonos os caciques algumas de suas mulheres, sob a alegação de que eles consideravam coisa contrária à natureza a circunstância de homens se ocuparem em trabalhos domésticos, quais os de cozinhar, varrer e outros deste tipo.

Seguiu-se o diálogo entre os padres e o referido cacique. Os padres informaram que organizavam sua casa, cercando com paus para impedir a entrada de mulheres. De outra parte, o cacique testemunhou estranhar tal comportamento, dizendo que entre os gentios a honra de sua autoridade consistia em ter muitas mulheres e criadas. De acordo com Montoya (1997, p. 60 ), essa prática “[...] vem a ser uma falta não pouco comum entre os gentios".

A atmosfera dessas divergências ganha ares mais contundentes a partir do relato de conflito entre os padres e o cacique Roque Maracanan de um povoado que estava a três léguas de Loreto. Esse cacique recebe adjetivações bastante negativas na descrição feita pelo jesuíta: 
"[...] era ele um verdadeiro ministro do demônio. Ele era desonesto em extremo, porque tinha grande número de concubinas" (MONTOYA, 1997, p. 60-61). A relação entre tal cacique e os jesuítas foi tensa, pois o líder dos gentios "[...] começou a perturbar e rebelar os ânimos de seus vassalos [...]" contra os padres (MONTOYA, 1997, p. 61). Em um desses momentos, Montoya (1997, p. 61) relata que Roque Maracanan disse:

Foram os demônios que nos trouxeram estes homens, pois querem, com novas doutrinas, privar-nos do que é antigo e do bom modo de viver de nossos antepassados. Tiveram estes muitas mulheres, muitas criadas e liberdade em escolhê-las a seu bel-prazer, sendo que agora pretendem que nos liguemos a uma só mulher. Não é justo que isso continue assim, mas impões que os desterremos de nossas terras ou que lhes tiremos as vidas.

Ao lado das adjetivações negativas apregoadas ao referido cacique, o jesuíta (MONTOYA, 1997, p. 61) registra: "[...] havia entre eles [gentios] muitos que nos tinham amor e estimavam a virtude, o bom exemplo e nossa doutrina. Afastaram-no eles de seus planos, avisando-lhe que não lhes parecia acertado ou bom pôr em prática isso, sem o parecer e consulta de Roque Maracanan”. A situação do cacique Maracanan não foi a única nas terras das missões. Padre Montoya descreve a confrontação com Miguel Artiguaye, outro líder dos gentios. Segundo relato desse jesuíta, o referido cacique teria dito:

Vós não sois sacerdotes enviados de Deus para nosso remédio (e bem)! Sois, pelo contrário, demônios do inferno, mandados de seu príncipe para a nossa perdição! Que espécie de doutrina é esta que nos trouxeste? Qual o descanso (a paz) e o contentamento? Nossos maiores viveram com liberdade, tendo para seu bem as mulheres que queriam, sem que ninguém nisso os estorvasse, com as quais viveram e passaram os seus dias com alegria. Vós, no entanto, quereis destruir as suas tradições e impor-nos uma carga tão pesada, como é a de atar-nos com uma mulher (MONTOYA, 1997, p. 62).

O desfecho desse conflito é bastante interessante, pois constrói uma imagem heterogênea dos povoados existentes em Guairá e reafirma a ideia da missão pacificadora dos jesuítas. No relato de Montoya, consta que o Miguel Artiguaye reuniu cerca de 300 soldados e foi solicitar autorização ao cacique Maracanan para pôr fim à presença dos padres nessas missões. Nesse intervalo, o cacique Araraá sugere que os padres abriguem-se em seu povoado, onde seriam protegidos da ira de Miguel. Porém, os padres decidiram aguardar em suas próprias casas os acontecimentos, entregando-se em orações, "[...] pois esta é mais poderosa que as armas" (MONTOYA, 1997, p. 64). O acontecimento seguinte foi que Maracanan desautorizou a iniciativa de Miguel, restando a este chegar aos padres e pronunciar-se de joelhos prostrados:

Por amor de Jesus Cristo e de Santo Inácio lhes rogo que me perdoeis o desacato que, como néscio, fiz contra vós! Estava eu louco e sem juízo. Agora já o tenho, porque Deus castigou minha soberba, e assim vos peço que me perdoeis. E, visto que tendes pregado a facilidade com que Deus perdoa aos que $\mathrm{O}$ ofendem, imitai-O vós em perdoar-me a mim! Ao mesmo tempo vos peço que me ampareis e defendais, porque eu temo com razão que esta gente me mate! Bem mereço, aliás, a morte por minhas loucuras. Mas vós, como verdadeiros padres ("pais") e servos de Deus, haveis de perdoar-me e me amparar (MONTOYA, 1997, p. 65). 
Miguel foi amparado e abraçado por Padre José, envolvendo-o em seus braços, sem deixar de dizer: "[...] que de agora em diante tomasse cuidado de si próprio e escolhesse o verdadeiro caminho, pois tinha experimentado quão mal lhe haviam saído suas quimeras" (MONTOYA, 1997, p. 66). O final desse acontecimento que ganhou quase a totalidade das linhas do item XI - "nosso modo de tirar tais abusos e de pregar a fé" e a integralidade do item XII - "a saída desse cacique do seu povo, para o propósito de seu mau intento ir consultar-se com Roque Maracana, e o que então lhe sucedeu", traz indícios da complexidade das relações que se estabeleciam, pois mostra que o cacique Miguel, de modo repentino, passou a reconhecer a sua não retidão e o poder desses padres. Entretanto, ao final, Padre Montoya (1997, p. 66) descreve que Miguel encenou toda aquela situação e descreve: "[...] fingiu que despedia sua manceba, que fora a causa de tais alvoroços. $\mathrm{E}$ trouxe para sua casa sua verdadeira mulher, com a qual ao menos no exterior dava a impressão de bem viver, mas sempre viveu mal, sendo que assim morreu".

Conforme Venturini (2009, p. 39 apud SOSTER, 2014, p. 66), “[...] o desafio maior dos missionários era conseguir a mudança de traços culturais dos índios, incompatíveis com o cristianismo". E um desses elementos de incompatibilidade, emenda Soster (2014, p. 66), “[...] estava relacionado à poligamia praticada por direito pelos caciques, que podiam ter as mulheres que pudessem proteger e sustentar". Por sua vez, "[...] como parte de sua estratégia para eliminá-la, os padres inseriram junto aos habitantes o uso de vestes e estas passaram a ter significado de identidade, poder e status" (SOSTER, 2014, p. 66-67).

Em regra, as descrições de Montoya encetam aos caciques e pajés a alcunha de inimigos da verdade e de encarnação do demônio. As descrições selecionadas indicam a multifacetada relação nas terras das missões. Um dos casos mais conhecidos é do cacique e pajé Taubici. Montoya (1997, p. 51) narra sua chegada a um povoado e seu encontro com esse líder: "[...] era um grande cacique, além de mago, de feiticeiro e familiar do demônio. Chamava-se Taubici: o que quer dizer diabos em fila ou fileira de demônios. Era ele muito cruel e, a partir de qualquer motivo de queixa, fazia matar os índios" (MONTOYA, 1997, p. 51).

Além do mais, observa Montoya (1997, p. 51): “[...] quando ele queria falar com o demônio, mandava que todos saíssem de sua casa e não ficassem em volta". A descrição da morte desse líder é marcada pelo enredo maniqueísta:

indo muito contentes o trajeto de sua viagem, fazendo burla e chacota do padre [Simão] e de suas admoestações e ameaças, e já chegando perto de seu povoado, que distava do de Santo Inácio 20 léguas, perceberam que havia índios no rio com as suas canoas. Foi ter com eles Taubici, pensando que eram amigos. Esse contudo, logo que o reconheceram, mataram-no em vingança de um índio que ele havia matado. Seus companheiros puseram-se em fuga. Muitos resultaram feridos, mas outros saltaram em terra. Voltaram estes sem o seu caudilho e, bem ensinados com tal castigo, tornaram a não crer nos ministros do demônio e acreditar nos de Deus, sendo que com isso o Evangelho logrou não pouco êxito (MONTOYA, 1997, p. 52).

Visto que os missionários estavam conformados pela visão de que deveriam cristianizar e civilizar os gentios, as relações foram demarcadas pelo maniqueísmo, caracterizando alguns caciques e pajés como a própria encarnação do demônio ${ }^{8}$. Esse aspecto explicita a complexidade

\footnotetext{
${ }^{8}$ A demonização demarcou a relação entre europeus e gentios. Sugerimos consultar as clássicas obras de Laura Melo e Souza O Diabo e a Terra de Santa Cruz: feitiçaria e religiosidade popular no Brasil colonial (1986) e Inferno Atlântico: demonologia e colonização - séculos XVI-XVIII (1993). As descrições de Padre Montoya estão inscritas nesse
} 
das missões, pois conforme Silvio Ruiz Paradiso (2012, p. 202), a “[...] divisão maniqueísta que se formava entre toda população das margens dos rios Paraná, Uruguai e do rio Tape era inegável”. Essa condição resultou na luta entre o bem e o mal, “[...] fomentada pelos jesuítas, cujas legiões dessa guerra se formavam entre o clero e os índios convertidos contra pajés e xamãs e os índios rebeldes, liderados por Jesus e pelo diabo respectivamente" (PARADISO, 2012, p. 202).

De outro modo, nesse movimento ganhou relevância a estratégia de associar os elementos culturais europeus aos dos gentios, como assinala Claudia Inês Parellada.

A linguagem visual encontrada nas telhas articula-se com a simbologia jesuíta, a mitologia Guarani, o cotidiano das missões, a alfabetização e a experimentação de motivos decorativos. [...] Encontram-se marcas da Companhia de Jesus e assinaturas de jesuítas, bem como o contorno de igrejas, embarcações, animais, cuja temática parece ser relacionada tanto aos mitos Guarani quanto ao processo de evangelização na fé católica (PARELLADA, 2013, p. 12).

Em síntese, a exposição deste item tratou de indicar que as relações sociais nas missões jesuíticas eram multifacetadas, demarcadas por confluências e por muitos conflitos, como documenta o diário de Padre Montoya e bem sintetiza a pesquisa de Soster (2014, p. 61-80) ao sumariar os debates do campo das ciências humanas.

\section{Considerações finais}

Este artigo inscreveu-se no debate sobre a atuação da Companhia de Jesus nas missões, privilegiando um olhar sobre as estratégias estabelecidas por Padre Montoya no processo de organização das reduções do Guairá. Assim, sem deixar de considerar que nos seus escritos "[...] os gestos extraordinários, a virtude incorruptível e a fé a toda prova de missionários sobrehumanos, cercados de perigos e inimigos diabólicos, converteram-se nos fios de uma narrativa legendária que sacralizou o passado" (OLIVEIRA, 2015, p. 103-104), buscou-se perceber como a presença dos jesuítas foi demarcada pela denúncia de abusos contra os gentios praticados pelos colonos espanhóis e bandeirantes paulistas, pela descrição elogiosa dos gentios convertidos e pelo combate contra gentios não convertidos, em especial contra caciques e pajés que eram representados como a encarnação do demônio nas terras das Américas.

As terras e os povos da região do Guairá compuseram o projeto de colonização da Coroa espanhola. Além disso, por ser região de fronteira entre os poderes espanhóis e portugueses a situação mostrava-se mais emblemática. $\mathrm{O}$ destino histórico dessas terras estava circunscrito ao expansionismo e à exploração de riquezas. Os gentios estavam contidos nesse projeto, transformados em mão de obra para realização dos mais variados serviços que se faziam necessários. Ademais, desde o início, a colonização levava consigo a estratégia de cristianização desses grupos. As reduções comandadas pelos colonos contavam com auxílio de padres. No entanto, o convite feito aos jesuítas para que se fixassem e fundassem sedes religiosas nas regiões da colonização constituiu-se em uma estratégia mais efetiva de conversão e arregimentação de novos cristãos, na expectativa, também, de que o domínio político da Coroa espanhola se desse com menor violência física.

contexto. Sugerimos consultar o capítulo de livro A demonização em A Conquista Espiritual (1639), de Antonio Ruiz de Montoya e na Festa de S. Lourenço (1587), de José de Anchieta, escrito por Silvio Ruiz Paradiso (2012). 
A ação dos jesuítas foi intensa nas terras das missões, chegando a 100 mil gentios batizados por Padre Montoya (PARADISO, 2012). Uma das frentes da colonização foi de responsabilidade da Igreja Católica. Nas terras das missões, aos padres da Companhia de Jesus coube a tarefa de promover estratégias para a conquista espiritual entre os gentios. Dessa maneira, destacamos os escritos desse jesuíta que evidenciam a confrontação aos abusos praticados pelos colonos e pela própria Coroa espanhola, o combate às invasões das reduções e aprisionamento de gentios feitos pelos bandeirantes, a conversão e cristianização dos povos das missões, a identificação de representações e práticas como encarnação do demônio. Essas estratégias estavam contidas no interior da conformação do habitus.

Assim sendo, a atuação dos jesuítas não estava contida apenas na ideia do colono ou da Coroa espanhola. Igualmente, não estava reduzida às representações e práticas dos gentios. Movidos pelo interesse de cristianização e pela perspectiva de pacificação dos gentios, a cruzada desses padres foi demarcada pela desnaturalização da violência física praticada nas terras das missões, como deixam perceber as descrições de Montoya. O binômio paz-violência tem marca forte em suas narrativas, pois não apenas aos colonos espanhóis e aos bandeirantes são atribuídas ações de crueldade, mas também a alguns caciques que matavam sem parcimônia. De outra parte, a ação dos missionários é, recorrentemente, caracterizada pela humildade, ascese e pelo diálogo. Essas representações e práticas geraram aproximações com os gentios, pois os padres eram um braço da Coroa espanhola e mostravam-se empenhados em fazer cumprir os preceitos de cidadania que se estendiam aos povos da colônia.

Ao mesmo tempo, a cristianização conformou as relações com os gentios, pois a institucionalização dos símbolos católicos, de rituais, de costumes e as práticas dos padres, como a observância da castidade, corroboraram no processo de organização das missões. O estranhamento, em relação aos ritos dos guaranis, não deixava de existir, conforme observa-se nos escritos de Montoya. No entanto, nas descrições dos costumes dos gentios estava contida a perspectiva de sua correção por meio da conversão e da pertença à comunidade católica das reduções, o que explicita a própria ideia de redução, de presença permanente e não mais missão itinerante.

Não obstante, a cristianização implicou em forte combate aos gentios não convertidos, pois como bem analisou Silvio Paradiso (2012, p. 204), eles “[...] eram constantemente demonizados, a fim de garantir aos índios convertidos que estes fizeram a escolha pelo bem". Mais do que isso, os caciques e pajés foram pintados como os rebeldes, "[...] empenhados em desmoralizar os padres e a doutrina cristã. Os pajés eram outremizados pelos religiosos, recebendo adjetivos variados como: miserável, familiar ao diabo, feiticeiros, magos, fingidos" (PARADISO, 2012, p. 204). Portanto, esses elementos destacados evidenciam a complexidade das relações sociais que se estabeleceram nas terras das missões do Guairá.

\section{Referências}

AGUILAR, Jurandir Coronado. Conquista Espiritual: A História da Evangelização na Província Guairá na obra de Antônio Ruiz de Montoya, S. I. (1585- 1652). Roma, EPUG, 2002.

BOURDIEU, Pierre. Coisas ditas. São Paulo: Brasiliense, 2004.

BOURDIEU, Pierre. A Economia das Trocas Linguísticas: O que Falar Quer Dizer. São Paulo: Editora da Universidade de São Paulo, 2008.

BOURDIEU, Pierre. Esboço de uma teoria da prática. In: ORTIZ, Renato (Org.). A sociologia de Pierre Bourdieu. São Paulo: Olha d'água, 2003, p. 39-72.

BOURDIEU, Pierre. As regras da arte: génese e estrutura do campo literário. Lisboa: Presença, 1996. 
BRUXEL, Arnaldo; RABUSKE, Arthur. Apresentação do texto vernáculo luso-brasileiro. In: MONTOYA, Antônio Ruiz. Conquista Espiritual: feita pelos religiosos da Companhia de Jesus nas Províncias do Paraguai, Paraná, Uruguai e Tape. 2. ed. Porto Alegre: Martins Livreiro, 1997. p. 9-10.

FUTATA, Marli Delmônico de Araújo; TOLEDO, Cézar de Alencar Arnaut de. A ação missionária do Padre Antonio Ruiz de Montoya no Guairá, no início do século XVII, Revista Teoria e Prática da Educação, v.20, n.1, p.63-74, Jan/Abr. 2017. https://doi.org/10.4025/tpe.v20i1.44755

LE GOFF, Jacques. História e memória. Campinas: UNICAMP, 1994.

MONTOYA, Antônio Ruiz. Conquista Espiritual: feita pelos religiosos da Companhia de Jesus nas Províncias do Paraguai, Paraná, Uruguai e Tape. 2. ed. Porto Alegre: Martins Livreiro, 1997.

MOURA, Gabriele Rodrigues. "Señores de la palavra”: Histórias e Representações na obra de Antonio Ruiz de Montoya (1612-1652). 2013. 275f. Dissertação (Mestrado em História) Programa de Pós Graduação em História, UNISINOS, São Leopoldo, 2013.

OLIVEIRA, Paulo Rogério Melo. Clio na Companhia de Jesus: notas sobre a historiografia jesuítica das reduções do Paraguai. Revista de Teoria da História, v. 14, n. 2, p. 78-108, nov. 2015.

PARADISO, Silvio Ruiz. A demonização em A Conquista Espiritual (1639), de Antonio Ruiz de Montoya e na Festa de S. Lourenço (1587), de José de Anchieta. In: MAGALHÃES, Antonio Carlos de Melo et al. (Orgs). O demoníaco na literatura. Campina Grande: EDUEPB, 2012. p. 199-214. https://doi.org/10.7476/9788578791889.0015

PARELLADA, Claudia Inês. Arte e espacialidade nas cidades colônias espanholas (1554-1632) e nas missões jesuíticas do Guairá (1610-1631). Revista Memorare, v. 1, p. 250-256, 2013. https://doi.org/10.19177/memorare.v1e12013250-256

PÁEZ, Sergio Luis Alberto. Las reducciones jesuíticas-guaraníes como antecedente de organización espacial en la región misionera. Contribuciones Científicas GAEA, v. 25, p. 165-173, 2013.

PICANÇO, Jefferson de Lima; MESQUITA, Maria José M. de. O cristal, o ferro e o sal: recursos minerais do antigo Guairá (1557-1632), atual estado do Paraná. Revista Terrae Didática, v. 6, n. 2, p., 2010. https://doi.org/10.20396/td.v6i2.8637454

REBES, Maria Isabel Artigas. Antônio Ruiz de Montoya: testemunha de seu tempo. 2001. 400 f. Dissertação (Mestrado em História) - Programa de Pós-Graduação em História, UNISINOS, São Leopoldo, 2001.

SILVA, André Luis Freitas. Reduções jesuítico-guarani: espaço de diversidade étnica. 2011. Dissertação (Mestrado em História) - Universidade Federal da Grande Dourados, Dourados, 2011.

SOSTER, Sandra Schmitt. Missões jesuíticas como sistema. 2014. Dissertação (Mestrado em Arquitetura e Urbanismo) - Universidade de São Paulo, São Carlos, SP, 2014.

SOUZA, Laura Melo. O Diabo e a Terra de Santa Cruz: feitiçaria e religiosidade popular no Brasil colonial. São Paulo: Companhia das Letras, 1986.

SOUZA, Laura Melo. Inferno Atlântico: demonologia e colonização - séculos XVI-XVIII. São Paulo: Companhia das Letras, 1993. 